\title{
Extent of Usage of Social Network Sites (SNSS) By Adolescents Studying Professional and Non Professional Courses
}

\author{
Amruta Malatesh Gonal ${ }^{1 *}$, Dr. L. Umadevi ${ }^{2}$
}

\section{ABSTRACT}

The present study extent of usage of Social Network Sites (SNSs) by adolescents studying Professional and Non Professional courses was taken up to know the when the adolescents started using the SNSs, the frequency of logging in these sites and the amount of time spent by them in these sites. The study further tries to find whether there is any gender difference and difference between professional and non professional course students in usage of social networking sites

Keywords: Social Network Sites, Adolescents, Professional and Non Professional Courses

Social networking sites are a dominant web presence that greatly influences the formation of individual identity through digital communication and interaction. "Despite its diversity and vast applications, the key to social media is the interaction. Standard media traditionally broadcasts its message via television, newspapers and radio. It is a one-sided conversation. Social media, on the other hand, is a two-sided conversation. It not only educates the audience, but it also allows the audience to participate in the discussion” (Harris). Within the realm of social media are the growingly popular social networks. A social networking service focuses on building and reflecting social networks and relationships among people who share interests, activities or other similarities. A social networking service essentially poses a virtual representation of a user, called a profile. This profile often features the user's basic information, such as age, location and sex, as well information regarding one's hobbies, such as favorite movies, musical artists and books. Users are encouraged to connect to one another using a variety of communication tools. These include public profile messages, private e-mail messages, instant messages and gifts. Social networking services rely on user participation and user-generated content. Both features not only provide the basis for which these sites may exist, but they enhance the usability and resulting popularity of the service. The most popular social networking services include MySpace, Facebook, and Twitter. Many adolescents begin and end their day by checking SNS posts.

\footnotetext{
${ }_{1}^{1}$ M.Sc. Dept Of Human Development And Family Studies, College Of Homescience PJSTAU, Hyderbad

2 Professor, Dept Of Human Development And Family Studies, College Of Homescience PJSTAU, Hyderbad *Corresponding Author

(C) 2015 I A Gonal, L Umadevi; licensee IJIP. This is an Open Access Research distributed under the terms of the Creative Commons Attribution License (http://creativecommons.org/licenses/by/2.0), which permits unrestricted use, distribution, and reproduction in any Medium, provided the original work is properly cited.
} 


\section{OBJECTIVE:}

To know the extent of usage of Social Network Sites (SNSs) by adolescents studying Professional and Non Professional courses

\section{METHODOLOGY:}

\section{Research Design}

Based on the nature of the problem and objectives, ex-post facto research design was adopted for conducting this study

\section{Locale of the Study}

Hyderabad and secunderabad from the state of Telangana was purposively chosen as the locale of the study because of the convenience of the investigator to carry out the work in terms of time, effort and money

\section{Sample and Sampling Procedure}

\section{Selection of sample}

- purposive sampling procedure was used to select sample for the present study

- sample comprised of 200 adolescents with equal number of boys and girls

\section{Sampling Procedure}

Criteria for sample selection are;

1. Age range of adolescents should between 18-20 years

2. Students studying graduation from professional and non-professional colleges

Table 1

\begin{tabular}{|l|l|l|l|}
\hline Age & Boys & Girls & Total \\
\hline 18 years & 29 & 25 & \\
19 years & 55 & 50 & 54 \\
20 years & 16 & 25 & 105 \\
& & & 41 \\
\hline Total & 100 & 100 & 200 \\
\hline
\end{tabular}

\section{Tools Used}

Ameasurement tool was developed for the study. Questionnaire is divided into five parts. part-1 covers the general information of respondents.. Part-2 covers questions on pattern of usage of social network sites and covers extent of usage of social network sites 
RESULTS AND DISCUSSION

Table 2 Details of Initialization of usage of social networking sites by late adolescents $\mathrm{N}=200$

\begin{tabular}{|c|c|c|c|c|c|c|c|c|c|c|c|c|c|}
\hline \multirow[t]{3}{*}{$\overline{\text { S.No }}$} & \multirow{3}{*}{$\begin{array}{l}\text { Dimension } \\
\text { Initialization of } \\
\text { usage }\end{array}$} & \multicolumn{4}{|c|}{$\begin{array}{l}\text { Professional } \\
\text { adolescents } \\
(\mathrm{n}=100)\end{array}$} & \multirow{2}{*}{\multicolumn{2}{|c|}{ Total }} & \multicolumn{4}{|c|}{$\begin{array}{l}\text { Non professional } \\
\text { adolescents } \\
(\mathrm{n}=100)\end{array}$} & \multicolumn{2}{|c|}{ Total } \\
\hline & & \multicolumn{2}{|c|}{$\begin{array}{l}\text { Girls } \\
(n=50)\end{array}$} & \multicolumn{2}{|c|}{$\begin{array}{l}\text { Boys } \\
(n=50)\end{array}$} & & & \multicolumn{2}{|c|}{$\begin{array}{l}\text { Girls } \\
(n=50)\end{array}$} & \multicolumn{2}{|c|}{$\begin{array}{l}\text { Boys } \\
(n=50)\end{array}$} & \multicolumn{2}{|c|}{$(n=100)$} \\
\hline & & $\mathbf{F}$ & $\%$ & $\mathbf{F}$ & $\%$ & $\mathbf{F}$ & $\%$ & $\mathbf{F}$ & $\%$ & $\mathbf{F}$ & $\%$ & $\mathbf{F}$ & $\%$ \\
\hline 1 & Below 6 month & 2 & 4 & 2 & 4 & 4 & 4 & 2 & 4 & 3 & 6 & 5 & 5 \\
\hline 2 & $\begin{array}{l}7 \text { months to }-1 \\
\text { year before }\end{array}$ & 9 & 18 & 5 & 10 & 14 & 14 & 8 & 16 & 13 & 26 & 21 & 21 \\
\hline 3 & $\begin{array}{l}1-2 \text { years } \\
\text { before }\end{array}$ & 12 & 24 & 8 & 16 & 20 & 20 & 14 & 28 & 7 & 14 & 21 & 21 \\
\hline 4 & $\begin{array}{l}\text { More than } 2 \\
\text { years before }\end{array}$ & 27 & 54 & 35 & 70 & 62 & 62 & 26 & 52 & 27 & 54 & 53 & 53 \\
\hline & Total & 50 & 100 & 50 & 100 & 100 & 100 & 50 & 100 & 50 & 100 & 100 & 100 \\
\hline
\end{tabular}

The initialization of using social networking sites was presented in the table. It is clearly evident that majority of selected sample started using SNS more than two years. Professional courses boys (70\%) and 54 percent of professional course girls initialized SNS more than two years ago. The study also reveals that 24 percent of girls in professional courses and 16 percent of boys in professional courses started using SNS from the last 1-2 years. It was interesting to note that in professional courses very less4 percent started using SNS sites six months before. The study further reveals that in non professional courses 52 percent of girls and 54 percent of boys started using SNS sites more than two years ago. A very less percentage of 4 percent girls and 6 percent boys in non professional courses initiated SNS usage just six months below. It is evident from the study that 28 percent of girls and 14 percent of boys started using SNS for the last -2 years. 


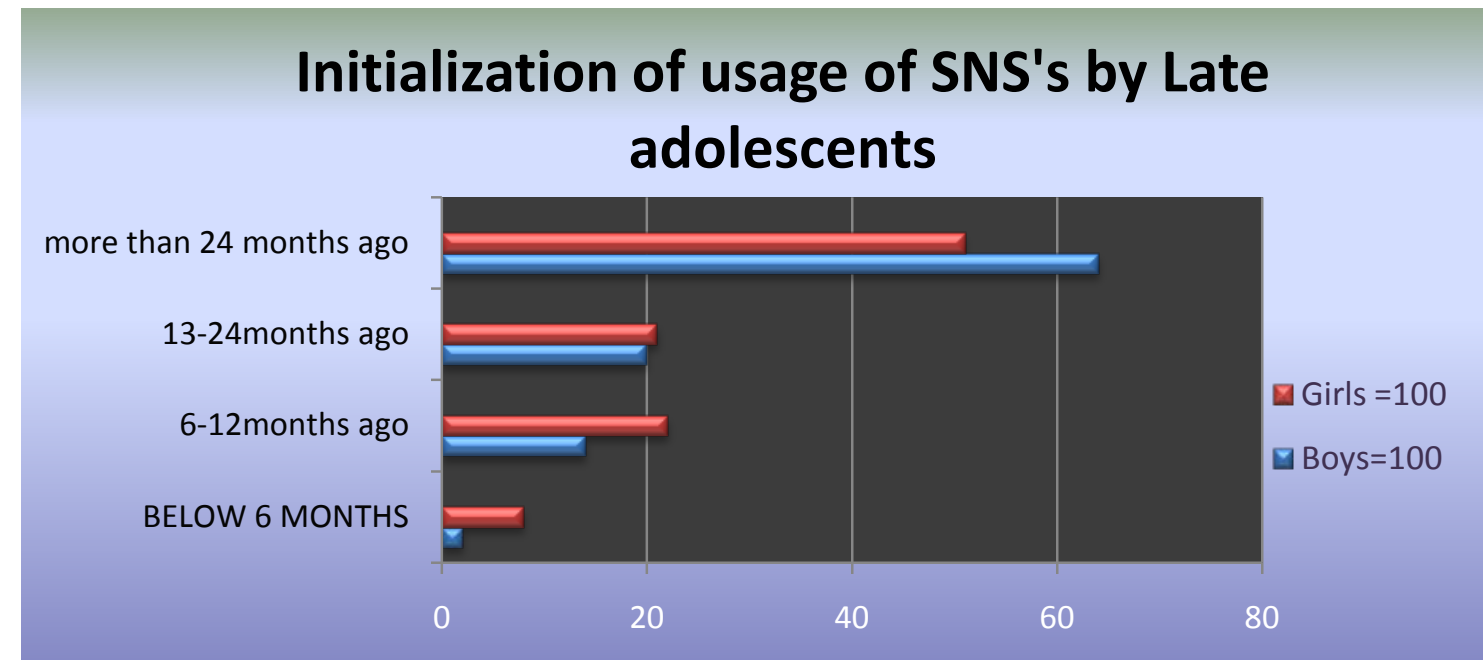

Fig-1 Initialization of usage of social networking sites by late adolescents

It can be concluded from the study that majority of the respondents from both professional and non professional courses irrespective of gender initialized SNS usage more than two years ago

\section{Initialization of usage of SNS's by Late adolescents}

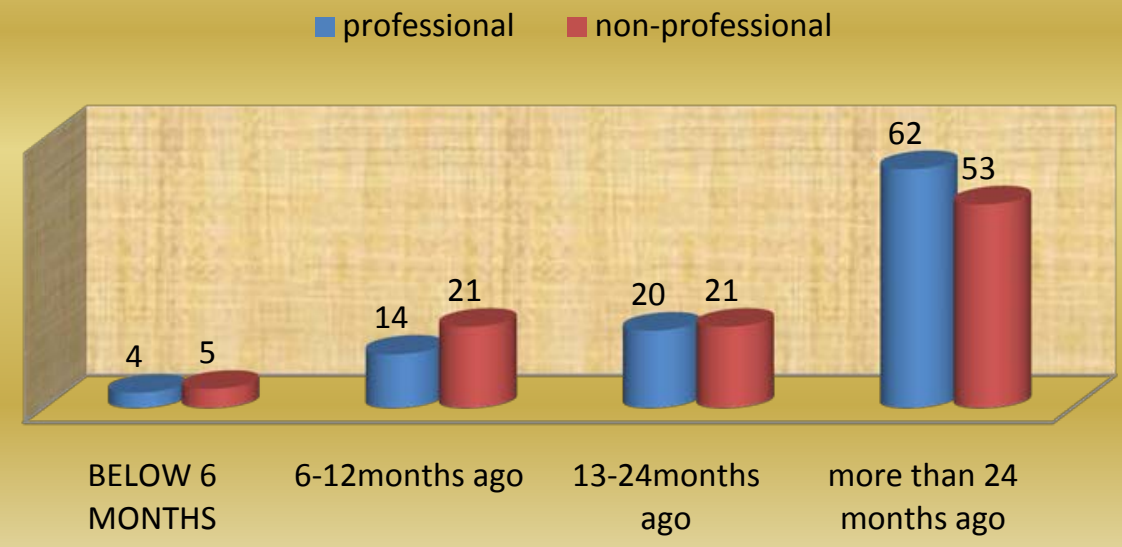

Fig-2 Initialization of usage of social networking sites by late adolescents

The result signifies that professional boys initiated their usage of social networking sites ahead of their other counterparts. 


\section{Extent of Usage of Social Network Sites (Snss) By Adolescents Studying Professional and Non Professional Courses}

Table 3. Frequency (percentage) of logging in SNS in One day by non-professional late adolescent

\begin{tabular}{|c|c|c|c|c|c|c|c|c|c|c|c|}
\hline \multirow[t]{2}{*}{ S.no } & \multirow[t]{2}{*}{ Sites } & \multicolumn{5}{|c|}{ Girls $(n=50) \%$} & \multicolumn{5}{|c|}{$\begin{array}{l}\text { Boys }(n=50) \\
\%\end{array}$} \\
\hline & & $\begin{array}{l}1 \\
\text { time }\end{array}$ & $\begin{array}{l}2 \\
\text { time }\end{array}$ & $\begin{array}{l}3 \\
\text { time }\end{array}$ & $\begin{array}{l}4 \\
\text { time }\end{array}$ & $\begin{array}{l}>4 \\
\text { time }\end{array}$ & $\begin{array}{l}1 \\
\text { time }\end{array}$ & $\begin{array}{l}2 \\
\text { time }\end{array}$ & $\begin{array}{l}3 \\
\text { time }\end{array}$ & $\begin{array}{l}4 \\
\text { time }\end{array}$ & $\begin{array}{l}>4 \\
\text { time }\end{array}$ \\
\hline 1 & Facebook & 18 & 16 & 10 & 6 & 50 & 14 & 22 & 20 & 10 & 34 \\
\hline 2 & Twitter & 8 & 13 & 5 & 2 & 1 & 9 & 14 & 12 & 2 & 0 \\
\hline 3 & YouTube & 8 & 7 & 39 & 45 & 1 & 11 & 17 & 24 & 31 & 4 \\
\hline 4 & $\begin{array}{l}\text { Google } \\
\text { plus }\end{array}$ & 19 & 14 & 4 & 4 & 0 & 27 & 11 & 4 & 4 & 4 \\
\hline 5 & $\begin{array}{l}\text { Linked } \\
\text { Inn }\end{array}$ & 7 & 7 & 2 & 1 & 0 & 14 & 9 & 7 & 1 & 0 \\
\hline 6 & Yahoo & 15 & 2 & 1 & 0 & 0 & 12 & 5 & 6 & 2 & 0 \\
\hline 7 & Skype & 3 & 4 & 9 & 11 & 3 & 5 & 3 & 8 & 11 & 2 \\
\hline 8 & Instagram & 4 & 4 & 5 & 4 & 0 & 12 & 5 & 2 & 0 & 0 \\
\hline 9 & $\begin{array}{l}\text { Google } \\
\text { talk }\end{array}$ & 2 & 3 & 3 & 4 & 0 & 1 & 5 & 10 & 2 & 0 \\
\hline 10 & Orkut & 5 & 6 & 3 & 1 & 0 & 8 & 4 & 4 & 0 & 0 \\
\hline 11 & $\begin{array}{l}\text { Any } \\
\text { other }\end{array}$ & 4 & 9 & 1 & 1 & 0 & 2 & 8 & 5 & 1 & 0 \\
\hline
\end{tabular}

The result of study clearly indicates that $50 \%$ of girls pursuing non professional courses log in Facebook more than 4 time in a day. Whereas only 34 percent of nonprofessional courses boys $\log$ in Facebook more than 4 times in one day. After face book, You tube which popular with late adolescents, girls of nonprofessional courses, 45 percent of them log in 4 times where as 31 percent of boys log in you tube 4 time a day. The study also reveals that 39 percent of girls and 24 percent of boys log in you tube three times a day. A very less percentage (1\% girls and $4 \%$ boys) log in you tube more than 4 times. The findings of study indicate that only $13 \%$ of non professional course girls and 14 percent boys log in twitter twice a day, whereas $8 \%$ of girls and 9 percent of boys log in twitter only once in a day. It is clearly evident from the table that 19 percent of girls and 27 percent of boys from non professional courses log in Google plus only once in a single day. The results of study show that very less percent of non professional students log in SNS like linked inn, Instagram, Google talk Orkut only once or twice in day. Therefore from the results of the study it can be concluded that Facebook, you tube, twitter are some of the popular SNS for late adolescents which login more number of times in a day than the other SNS. 


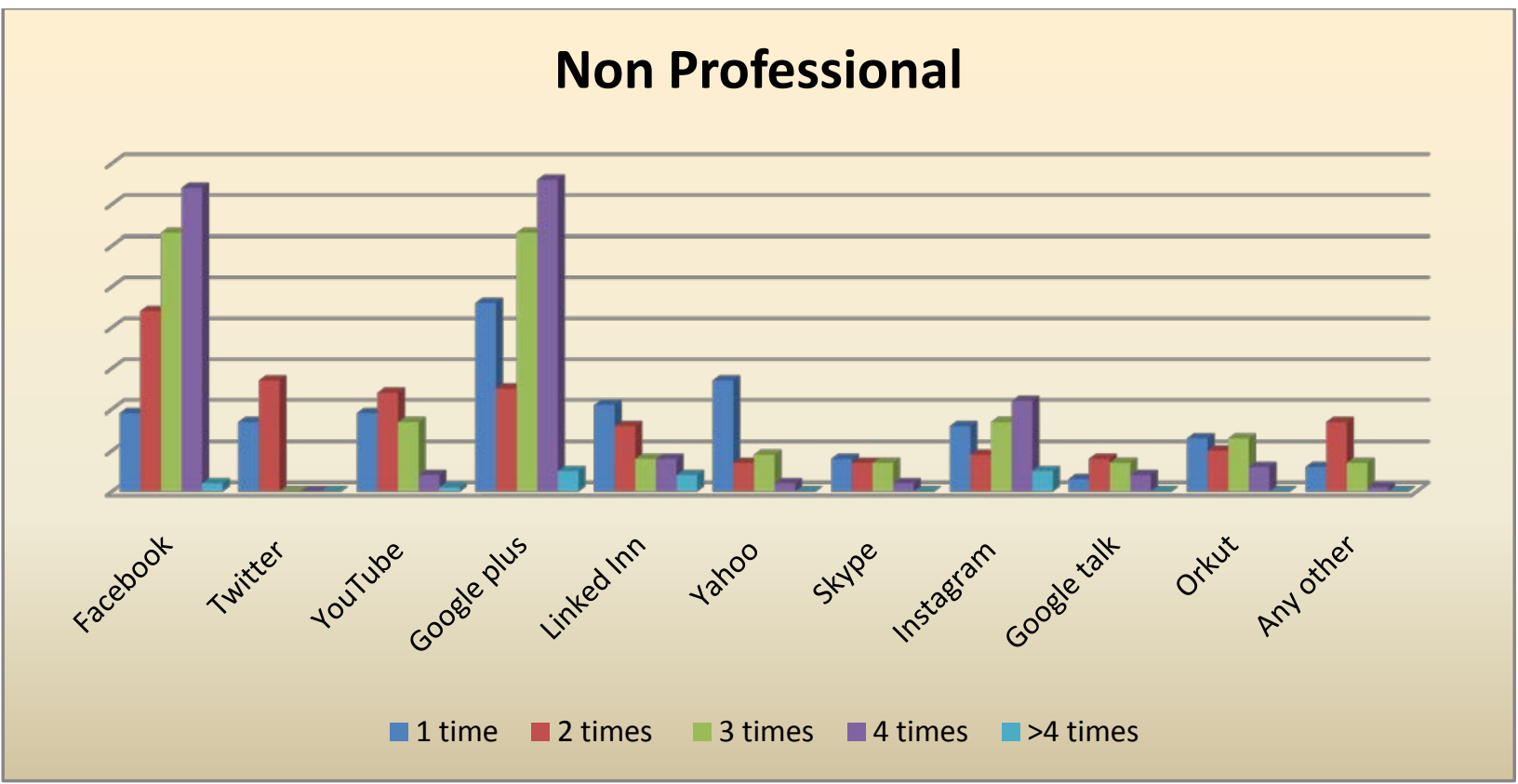

Fig-3 Frequency (percentage) of logging in SNS in One day by non-professional late adolescent

Pew (2013) found that 94\% Of Teenagers Use Facebook, Have 425 Facebook Friends, but Twitter \&Instagram Adoption way up. According to a recent poll by common sense media (2009), 22\% of teenagers log on to their favorite social media site more than 10 times a day, and more than half of adolescents $\log$ on to a social media site more than once a day.

Table 4. Frequency(percentage) of logging in SNS in One day by professional late adolescents

\begin{tabular}{|l|l|l|l|l|l|l|l|l|l|l|l|}
\hline S.no & Sites & \multicolumn{9}{|c|}{ Girls\%(n=50) } & \multicolumn{3}{l|}{ Boys \% (n=50) } \\
\hline & & $\begin{array}{l}\mathbf{1} \\
\text { time }\end{array}$ & $\begin{array}{l}\mathbf{2} \\
\text { time }\end{array}$ & $\begin{array}{l}\mathbf{3} \\
\text { time }\end{array}$ & $\begin{array}{l}\mathbf{4} \\
\text { time }\end{array}$ & $\begin{array}{l}\mathbf{> 4} \\
\text { time }\end{array}$ & $\begin{array}{l}\mathbf{1} \\
\text { time }\end{array}$ & $\begin{array}{l}\mathbf{2} \\
\text { time }\end{array}$ & $\begin{array}{l}\mathbf{3} \\
\text { time }\end{array}$ & $\begin{array}{l}\mathbf{4} \\
\text { time }\end{array}$ & $\begin{array}{l}>\mathbf{4} \\
\text { time }\end{array}$ \\
\hline 1 & Facebook & 26 & 20 & 28 & 6 & 20 & 26 & 30 & 22 & 8 & 14 \\
\hline 2 & Twitter & 4 & 18 & 5 & 1 & 1 & 9 & 16 & 7 & 2 & 3 \\
\hline 3 & YouTube & 5 & 4 & 15 & 21 & 43 & 11 & 5 & 14 & 16 & 42 \\
\hline 4 & $\begin{array}{l}\text { Google } \\
\text { plus }\end{array}$ & 19 & 14 & 6 & 2 & 0 & 21 & 18 & 7 & 1 & 0 \\
\hline 5 & $\begin{array}{l}\text { Linked } \\
\text { Inn }\end{array}$ & 6 & 9 & 2 & 0 & 0 & 20 & 7 & 4 & 0 & 0 \\
\hline 6 & Yahoo & 11 & 5 & 2 & 0 & 0 & 14 & 6 & 2 & 0 & 0 \\
\hline 7 & Skype & 23 & 5 & 2 & 0 & 0 & 11 & 16 & 2 & 0 & 0 \\
\hline 8 & Instagram & 3 & 3 & 6 & 4 & 1 & 9 & 5 & 2 & 1 & 0 \\
\hline 9 & $\begin{array}{l}\text { Google } \\
\text { talk }\end{array}$ & 1 & 5 & 5 & 1 & 0 & 6 & 2 & 1 & 9 & 0 \\
\hline 10 & Orkut & 7 & 2 & 3 & 0 & 0 & 7 & 5 & 4 & 0 & 0 \\
\hline 11 & $\begin{array}{l}\text { Any } \\
\text { other }\end{array}$ & 3 & 5 & 2 & 1 & 0 & 1 & 2 & 6 & 2 & 0 \\
\hline
\end{tabular}

The frequency of logging in SNS by Professional course students is given in above table. It is very interesting to note that majority of girls (28\%) log in face book three times in a day, 26 


\section{Extent of Usage of Social Network Sites (Snss) By Adolescents Studying Professional and Non \\ Professional Courses}

percent once and 20 percent of them log more than 4 times in face book in one day. However majority of boys pursuing professional courses (30\%) log in face book only twice a day. The finding of the study reveal that $43 \%$ of girls and $42 \%$ of boys log in you tube more than 4 times a day, while 21 percent girls and $16 \%$ of boys $\log$ in 4 times a day in you tube. The study findings indicate that only 18 percent of girls and 16 percent of boys from professional courses $\log$ in twitter only twice a day. The results of the point out that 19 percent of girls and 21 percent of boys login Google plus. It is surprising to note that very few late adolescents pursuing professional courses log in other social network sites like Linked inn, Instagram, Skype, Google talk. It can be concluded from the study that Facebook, you tube; twitter and Instagram are some of popular social network sites. Of all these majority of them log more number of times in Facebook.

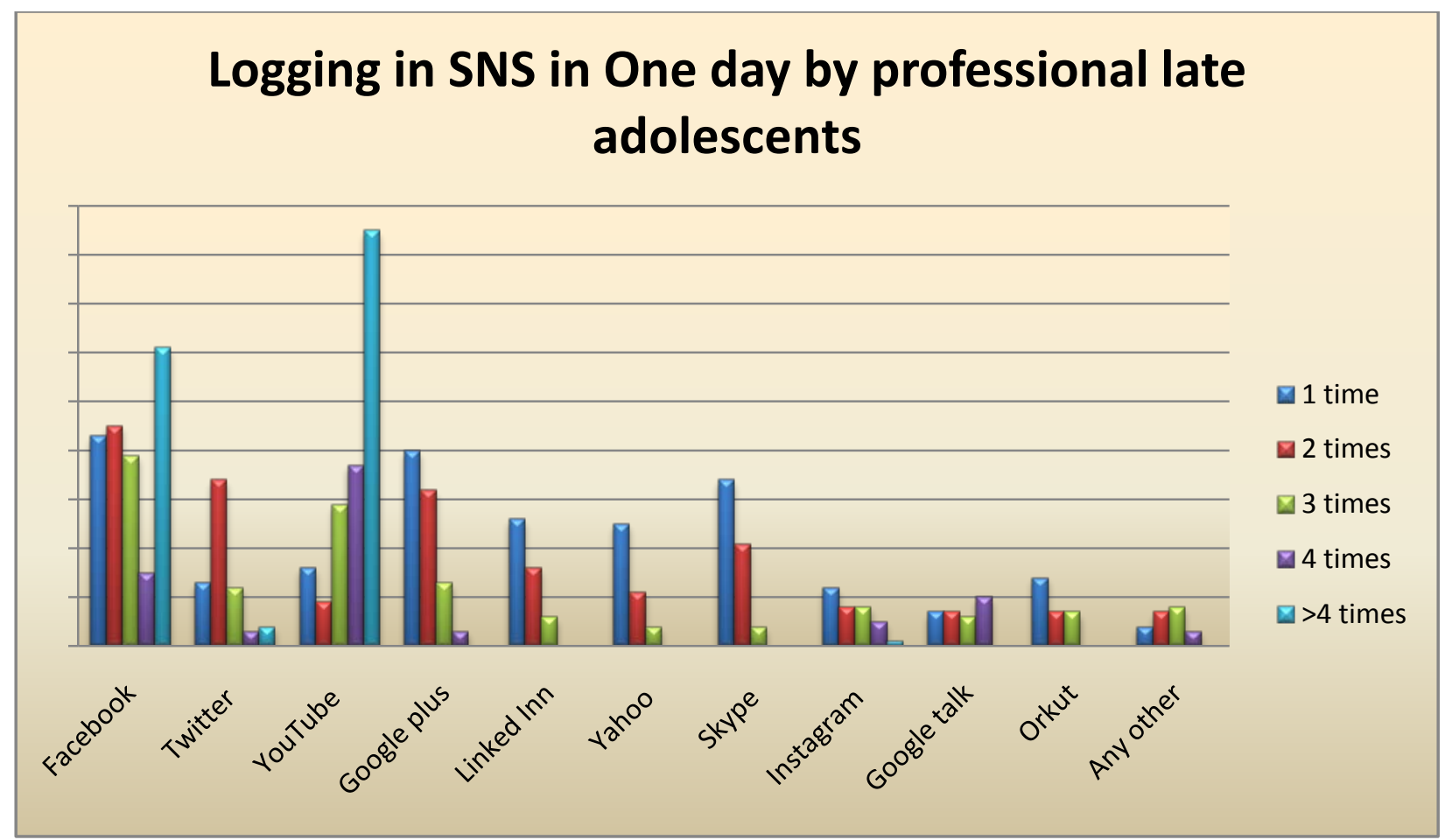

Fig-4Logging in SNS in One day by professional late adolescents 
Table 5 Amount of time spent in SNS's in a day by professional late adolescents

\begin{tabular}{|c|c|c|c|c|c|c|c|c|c|c|c|}
\hline \multirow[t]{2}{*}{ S.no } & \multirow[t]{2}{*}{ Sites } & \multicolumn{5}{|c|}{ Girls $\%(n=50)$} & \multicolumn{5}{|c|}{ Boys \%(n=50) } \\
\hline & & $\begin{array}{l}5 \\
\text { Mins }\end{array}$ & $\begin{array}{l}15 \\
\text { mins }\end{array}$ & $\begin{array}{l}30 \\
\text { mins }\end{array}$ & $\begin{array}{l}>30 \\
\text { mins }\end{array}$ & $\begin{array}{l}>1 \\
\text { Hour }\end{array}$ & $\begin{array}{l}5 \\
\text { mins }\end{array}$ & $\begin{array}{l}15 \\
\text { mins }\end{array}$ & $\begin{array}{l}30 \\
\text { mins }\end{array}$ & $\begin{array}{l}>30 \\
\text { mins }\end{array}$ & $\begin{array}{l}>1 \\
\text { Hour }\end{array}$ \\
\hline 1 & Facebook & 14 & 22 & 38 & 22 & 0 & 12 & 32 & 22 & 32 & 2 \\
\hline 2 & Twitter & 8 & 13 & 5 & 2 & 1 & 9 & 14 & 12 & 2 & 0 \\
\hline 3 & YouTube & 8 & 7 & 39 & 45 & 1 & 11 & 17 & 24 & 31 & 4 \\
\hline 4 & $\begin{array}{l}\text { Google } \\
\text { plus }\end{array}$ & 19 & 14 & 4 & 4 & 0 & 27 & 11 & 4 & 4 & 4 \\
\hline 5 & Linked Inn & 7 & 7 & 2 & 1 & 0 & 14 & 9 & 7 & 1 & 0 \\
\hline 6 & Yahoo & 15 & 2 & 1 & 0 & 0 & 12 & 5 & 6 & 2 & 0 \\
\hline 7 & Skype & 3 & 4 & 9 & 11 & 3 & 5 & 3 & 8 & 11 & 2 \\
\hline 8 & Instagram & 4 & 4 & 5 & 4 & 0 & 12 & 5 & 2 & 0 & 0 \\
\hline 9 & $\begin{array}{l}\text { Google } \\
\text { talk }\end{array}$ & 2 & 3 & 3 & 4 & 0 & 1 & 5 & 10 & 2 & 0 \\
\hline 10 & Orkut & 5 & 6 & 3 & 1 & 0 & 8 & 4 & 4 & 0 & 0 \\
\hline 11 & Any other & 4 & 9 & 1 & 1 & 0 & 2 & 8 & 5 & 1 & 0 \\
\hline
\end{tabular}

The findings on amount of time spent by late adolescents pursuing non professional courses is given in above table. The results of the study reveal that majority of girls (38\%) spend half an hour in Facebook and 22 percent of them spend more than thirty minute. However 32 percent of boys spend more than 30 minutes in face book and other 32 percent spend only 15 minutes in face book. It is surprising to note that 45 percent of girls spend more than 30 minutes on you tube whereas only 31 percent of boys spend more than thirty minutes on you tube. The finding further indicates that 39 percent of girls and 24 percent of boys spend 30 minutes in you tube. In SNS like google plus 19 percent of girls, 27 percent boys spend only 5 minutes. It is interesting to note from the study that time spent by late adolescents on twitter is only 15 minutes. For other SNS the time spent is very less. It can be concluded that Face book is the more popular site where late adolescent most of their time.

McAfee's Tweens, Teens \& Technology Report 2014 that in terms of social networking platforms, Facebook is by far the most popular site used (93\%), followed by YouTube (87\%) and WhatsApp (79\%). o 10-12 year old social account users report higher daily access to Snapchat, Pinterest. 
Extent of Usage of Social Network Sites (Snss) By Adolescents Studying Professional and Non Professional Courses

Table 6Amount of time spent in SNS's by non-professional late adolescents

\begin{tabular}{|c|c|c|c|c|c|c|c|c|c|c|c|}
\hline \multirow[t]{2}{*}{ S.no } & \multirow[t]{2}{*}{ Sites } & \multicolumn{5}{|c|}{ Girls $\%(n=50)$} & \multicolumn{5}{|c|}{ Boys $\%(n=50)$} \\
\hline & & $\begin{array}{l}5 \\
\text { mins }\end{array}$ & $\begin{array}{l}15 \\
\text { mins }\end{array}$ & $\begin{array}{l}30 \\
\text { mins }\end{array}$ & $\begin{array}{l}>30 \\
\text { mins }\end{array}$ & $\begin{array}{l}>1 \\
\text { Hour }\end{array}$ & $\begin{array}{l}5 \\
\text { mins }\end{array}$ & $\begin{array}{l}15 \\
\text { mins }\end{array}$ & $\begin{array}{l}30 \\
\text { mins }\end{array}$ & $\begin{array}{l}>30 \\
\text { mins }\end{array}$ & $\begin{array}{l}>1 \\
\text { Hour }\end{array}$ \\
\hline 1 & Facebook & 14 & 22 & 38 & 22 & 0 & 12 & 32 & 22 & 32 & 2 \\
\hline 2 & Twitter & 8 & 13 & 5 & 2 & 1 & 9 & 14 & 12 & 2 & 0 \\
\hline 3 & YouTube & 8 & 7 & 39 & 45 & 1 & 11 & 17 & 24 & 31 & 4 \\
\hline 4 & $\begin{array}{l}\text { Google } \\
\text { plus }\end{array}$ & 19 & 14 & 4 & 4 & 0 & 27 & 11 & 4 & 4 & 4 \\
\hline 5 & Linked Inn & 7 & 7 & 2 & 1 & 0 & 14 & 9 & 7 & 1 & 0 \\
\hline 6 & Yahoo & 15 & 2 & 1 & 0 & 0 & 12 & 5 & 6 & 2 & 0 \\
\hline 7 & Skype & 3 & 4 & 9 & 11 & 3 & 5 & 3 & 8 & 11 & 2 \\
\hline 8 & Instagram & 4 & 4 & 5 & 4 & 0 & 12 & 5 & 2 & 0 & 0 \\
\hline 9 & $\begin{array}{l}\text { Google } \\
\text { talk }\end{array}$ & 2 & 3 & 3 & 4 & 0 & 1 & 5 & 10 & 2 & 0 \\
\hline 10 & Orkut & 5 & 6 & 3 & 1 & 0 & 8 & 4 & 4 & 0 & 0 \\
\hline 11 & Any other & 4 & 9 & 1 & 1 & 0 & 2 & 8 & 5 & 1 & 0 \\
\hline
\end{tabular}

The above table presents the amount of time spent by non professional course late adolescents on Social networking sites. The study findings indicate that 38 percent of girls spend 30 minutes on face book while 32 percent of boys spend more than half an hour . The findings further indicate that 22 percent girls and 32 percent boys spend 15 minutes while only b2 percent of boys spend more than hour on Facebook. After Facebook majority of girls (45\%) and 31 percent of boys spend more than half an hour on you tube. In SNS like Google plus very less percentage (19\% girls and $27 \%$ boys) spend 5 minutes. In other social networks like Yahoo, skype, Instagram, Google talk Orkut very less percent ( $<10$ percent) of boys and girls spend their time. The amount of time spent on Facebook more than the time spent on other social networks, as Face book is most popular with adolescents irrespective of Gender.

\section{REFERENCES}

Back, M. D., Stopfer, J. M., Vazire, S., Gaddis, S., Schmukle, S. C.,Egloff, B., and Gosling, S. D. 2010. Facebook profiles reflect actual personality, not self-idealization. Psychological Science. 21: 372-374.

Barker, V. 2009.Older adolescents' motivations for social network site use: The influence of gender, group identity, and collective self-esteem.cyberpsychology\&Behavior.12(2):209213.

Bhola,R.M., Mahakud,G.C.2014. A qualitative analysis of social networking usage, International Journal of Research and Development of Health. 2(1): 34-44

Bond,B.J. 2009. 'He posted, she posted: gender differences in self-disclosure on social network sites,Rocky Mountain Communication Review; 6 (2): 29-37 


\section{Extent of Usage of Social Network Sites (Snss) By Adolescents Studying Professional and Non \\ Professional Courses}

Boyd, D.M. and Ellison ,N.B.2004. Social network sites: Definition, history, and scholarship. Journal of Computer-Mediated Communication.13:210-230.

Common Sense Media. 2009.Is Technology Networking Changing Childhood? A National Poll. San Francisco, CA: Common Sense Media; Availableat:www.commonsensemedia.org/sites/default/files/CSM_teen_social_ media_080609_FINAL.pdf. Accessed July 16, 2010

Manjunatha. S.2013, "The Usage of Social Networking sites Among the College Students in India” International Research Journal of Social Sciences,2(5):15-21

McAfee Tweens, Teens \& Technology 2014 report reveals One in Three Indian youth have been cyberbullied. India education dairy. 